\title{
A Great Citizen Is Still “Under-Construction”: The Conflicting Self-Identity in Sayonara 1945
}

\author{
LEE Shin-yi \\ China Medical University, Taichung, Taiwan
}

\author{
CHEN Jui-sung \\ Mingdao University, Changhua, Taiwan
}

\begin{abstract}
Sayonara 1945, performed by Golden Bough Theatre in 2010 in Taipei, was claimed to be a "Heart Taiwan Magical Musical”. This “Heart Taiwan Magical Musical” is actually an adaptation of Taiwanese Opela, a reformed and adapted style of Taiwanese local opera (gezaixi), which has been strongly influenced by Japanese Colonization. Sayanara 1945 fictionalizes a troop of Taiwanese youths who join the Imperial Army being lied and cheated to dig gold for the Japanese Emperor after the war is over. This play gives a conflicting scenario of being Taiwanese in 1945, while everything that defined Taiwanese suddenly turned out to be treason to the country. By adapting the form of Opela, the play structurally presents a society where diverse and plural cultural elements counteract each other in Taiwan. Furthermore, as the title suggests, the play says Sayonara (“Goodbye” in Japanese) to 1945, yet the confusion and conflict generated in 1945 still haunt Taiwanese society. In other words, the play responds to an on-going self-conflict of being Taiwanese that still continues even after the war and unto the present symbolically. Presented in the year before "the Republic of China" celebrated her hundredth birthday, this play portrays the anxiety about who the Taiwanese really are over the island, just like in the summer of 1945 when everything was also uncertain and confusing. This paper intends to discuss, by adopting the form and techniques of Opela, how this reformed Opela speaks for Taiwanese local arts and culture, and how the Taiwanese identity is framed and shaped ever since the colonization era.
\end{abstract}

Keywords: Opela, Sayonara 1945, Golden Bough Theatre, Taiwanese opera, Taiwanese identity, Japanese colonization, Japanization movement

\section{Introduction}

Sayonara 1945, performed by Golden Bough Theatre (金枝演社) in 2010 in Taipei, one year earlier before the Republic of China celebrated her 100th national birthday. Sayonara 1945 is also titled in Chinese, A March of Great Citizens (大國民進行曲/Da guo min jin xing qu). Both English and Chinese titles suggest 1945 is not only a watershed between Japanese Colonization and the Kuomintang Administration in Taiwan, but at this critical divide, Taiwanese people have experienced a political confusion about who they believe they are and who they really are. As WANG Rong-yu, director of this play, has put it, "[T]his play tells not only a simple story that took place in 1945, but provides a fable just as suitable for modern Taiwan. The illustration of 'One Country, Two

LEE Shin-yi, Ph.D., assistant professor, General Education Center, China Medical University.

CHEN Jui-sung, Ph.D., assistant professor, Department of English Studies, Ming-Dao University. 
Worlds' creates a vivid projection of how people feel at this current moment”. ${ }^{1}$ Wang would like to utilize this illustration of "One Country, Two Worlds" to point out the inner conflict of today's Taiwanese people, that although Taiwan has gone through several democratic revolutions, the anxiety about uncertain future and quest for a national identity still haunt the island. While the government celebrated with great pleasure the 100th national birthday of the Republic of China which actually reigns over Taiwan only after 1945, the doubt and anxiety about who Taiwanese really are also enhance simultaneously.

Golden Bough Theatre has been established in 1993, and claims to draw inspirations from local Taiwanese opera (i.e., Gezaixi/歌仔戲 in Chinese) and western theatrical practices. ${ }^{2}$ Its grassroots spirit and innovative ways of merging Taiwanese opera and modern theatre stand out above the other local theatrical troupes in Taiwan. Golden Bough Theatre has been best-known for its Opela productions, a hybrid form of Taiwanese local opera and foreign arts. Opela is a transliterated term from “opera” (オペラ) in Japanese, whose origin could be dated back to the colonization era. During Japanese Occupation Era (1895-1945), a lot of western theatrical ideas and practices were introduced to Taiwan by overseas Chinese and Japanese. Later on, due to the severe suppression of the Japanization Movement (Kominka Movement/皇民化運動, 1937-1945), Opela survived and boosted as the major public entertainment for Taiwanese people, when all Taiwanese indigenous arts were strictly censored and controlled. Opela has long been a street demonstration, played along with religious festivals or ceremonies. Golden Bough Theatre now promotes it as a high art to be performed in National Theatre. This shift of the performing locales of Opela is phenomenal, for it highlights this hybrid and somewhat vulgarized street art and reminds the audience of the colonial past on this island. In this paper, the authors would like to discuss, by adopting the form of Opela, how Taiwanese identity is presented in Sayonara 1945 and ever since the colonization era, and how the form of Opela represents one trait of Taiwanese identity.

\section{A False Glory of Being a Great Citizen}

Sayonara 1945 features a troop of Taiwanese youths who join the Imperial Army being lied and cheated by their superiors, Takabashi and Kobayashi, to dig gold for the Japanese Emperor, when the Pacific war is over in 1945. Then, Kobayashi asks help from a female traveling opera troupe to cover the truth and pretend they are Women's Volunteer Corp sent by the Japanese Government to comfort the soldiers. Kobayashi promises that once gold is found, he would share gold with all of opera performers. With the help from these opera performers, the soldiers are pacified and deeply believe once they succeed, gold would bring them good fortune and fame, and soon they all could return home with honor and wealth. However, as time flies, no gold is found and the opera performers find it more and more difficult to keep deceiving. Eventually, a soldier decides to run away with an opera girl. As he learns their plan, Takabashi is eager to stop them by killing the girl. In order to stop Takabashi, the master of the opera troupe, who turns out to be a secret agent of China, Tamsui Number 3, reveals the truth, and the soldiers finally come to realize all they believe is nothing but a lie, a dream they build in the air.

Structurally, in Sayonara 1945, there are a series of illusions and lies. Takabashi, unwilling to accept the

\footnotetext{
${ }^{1}$ This part is quoted from 1945, Dream On written by WANG Rong-yu from the pamphlet packed along with the DVD that recorded actual performance.

2 See the official website of Golden Bough Theatre, http://www.goldenbough.com.tw/ (25 March 2014). The major western practice is from the Grotowski training system.
} 
truth of being defeated, still hangs on his ambitious dream and imperial glory. In order to realize his dream, Takabashi conspires with Kobayashi and leads the troop to mine gold. He believes once gold is found, he could have enough supply to fight back and prove his loyalty to the Emperor. Kobayashi and the soldiers simply follow the order of mining and regard mining as a great contribution to the country. Meanwhile, the opera performers, who already know the truth that the war is over and Japan is no longer their home country, still consent to help realize the illusion for intriguing financial incentives. Despite the truth of losing the war, everyone in the play seems to believe the dream he or she is building and tries hard to make it come true.

The series of illusions and lies here in this play carry a double meaning. First, the ideal of the imperial glory and great citizens is only an illusion, a make-believe. The play begins with the Japanese Emperor's declaration of defeat in 1945. As the play reveals, Takabashi and Kobayashi are kneeling down in the background and prepare to commit suicide as they learn the war is over. In the meantime, down in the foreground, a group of young opera actresses sing the song of victory. Their master teaches them now the national language is no longer Japanese; they have to practice Mandarin Chinese. Soon, a band of soldiers appear onstage complaining that when the Japanese rule Taiwan, they have to learn Japanese; now if the Chinese come, they all have to learn Mandarin Chinese; they are always busy adjusting themselves to the new ruler. This scenario shows in 1945 everything that Taiwanese people used to be familiar or even identify with, such as language and the nation, suddenly turns out to be foreign and strange. Naturally, the idea of "great citizens" would be always challenged by different political powers. In fact, before 1945, the Japanese colonial government propagandized the idea of being an imperial subject was an honor for the Taiwanese, and the Chinese were the enemy. However, as Japan lost the war, the honor of being an imperial subject soon turned out to be treason, although the Chinese language could be as foreign as Japanese to Taiwanese people at that time. The very first scene just reveals the truth that Taiwanese people are not only between political reigns but between new national identities; yet, their identity is never defined by themselves. The real Japanese, like Takabashi, choose to die for honor, while the Taiwanese adjust themselves for survival. Under this condition, the idea of being great citizens is only a way out for survival under the colonial reign. As the play progresses, the need for survival and reuniting with the family for Taiwanese people stands out above the need for a national identity. Despite the fact that they are between two different political reigns, all Taiwanese characters in the play are busy covering or prevented from knowing the truth in order to survive, which makes the idea of imperial glory and great citizens that Takabashi propagandizes seem to be airy and vain.

Second, ironically, the series of illusions and lies presented in the play help the Taiwanese to recognize the truth that they are not unified and their lack of a core identity. In this play, Kobayashi and Haruko, the leading actress of the opera troupe, both are aware of the truth that the war is over, and work together to prevent the soldiers from knowing it. They could be seen as representative as how Taiwanese people come to realize the need to control their fate and define their own identity in the times of turbulence. In Act 3, seeing the soldiers being deceived and trapped in lies, Haruko starts to feel troubled by her sense of guilt. She constantly feels confused in her "play" of deception, asking herself who the winner is. Or is everyone the loser who has gold but loses the home (or the home country they used to believe)? Later in Act 4, Haruko decides to confront with Kobayashi and persuades him into ending their "play”. She thinks it is time to reveal the truth, and even blames Kobayashi for being coward to face the fact. Kobayashi replies all he wishes is love and survival, so that he could move onto his 
own life. He is reluctant to face the truth. It is until Takabashi threatens to kill Yokmui who decides to run away with the soldier, Ario, and the Chinese secret agent, Tamsui Number 3, stays indifferent and detached coldly from the possible murder, that Kobayashi realizes he is not Japanese or Chinese, for the Japanese or Chinese never regards him as one of them. He then shouts, "Taiwanese people should be unified” (Act 4). Surviving between different political powers, the desire for survival may suppress Taiwanese people from searching for a national identity; however, it is also the strong need to survive helps the Taiwanese realize their identity is torn and not unified. Presenting the change of Kobayashi's political stand, Sayonara 1945 points out the struggle of Taiwanese people during the war and colonization. The shift of political powers and suppressive colonial reigns result in the confusion and dilemma of Taiwanese people, but at the same time activates the desperate need for a national identity.

In this play, the most significant metaphor is the act of mining. On the surface, gold mining is an order from Takabashi, and the soldiers just follow it dutifully. Nevertheless, as they begin digging, the soldiers become hopeful and dream to be shrouded with gold when returning home. This act of mining then turns into a process of dream realizing. For these Taiwanese soldiers, following the order and then getting rewards could lead them to the path of success. Yet, the act of mining displays a submissive and docile body gesture here: bending, sweating, and laboring in darkness; these soldiers are invisible to the Japanese Emperor and even to China, their new ruler. This act of mining demonstrates a vivid contrast to the promise made by Takabashi and Kobayashi: They build the castle in the air, while the soldiers take actions to work for their dreams.

It is worth noting that by the end of the play, all characters find what really shines before them is not gold, but miscanthus flowers, a widespread wild plants in Taiwan. Miscanthus flowers survive even in harsh conditions; once cut or destroyed, they could always survive and bloom. Miscanthus flowers are a symbol of life-force and indigene. During the Japanese Occupation Era, many Taiwanese people would compare themselves as miscanthus flowers which bloom and thrive when being mistreated. ${ }^{3}$ In this play, all characters are eager to find gold, an expensive but dead substance to transform them and grant their wishes; however, what really gives rays of life is a native wild plant grown out of the soil. Miscanthus flowers are a reminder to all characters that they all have to move on despite the shift of governments:

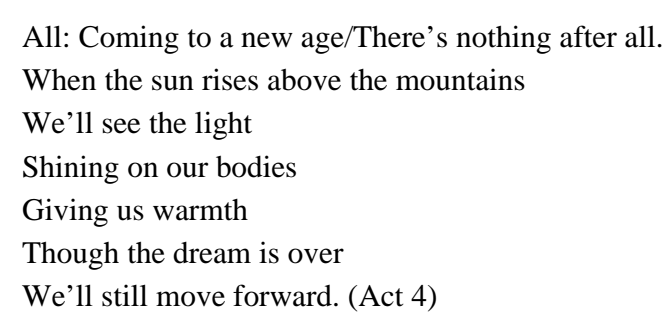

Ending with the image of miscanthus flowers, Sayonara 1945 does not seem to provide a solution to the identity dilemma of Taiwanese people. Facing the colonial past and the coming threat from China, Sayonara 1945 raises the question and reflection about whom Taiwanese people should identify with. However, the image

\footnotetext{
3 For example, in 1943, DENG Yu-xian (鄧雨賢/1906-1944), a Taiwanese musician, composed a song titled Miscanthus Flowers, depicting the strong life-force of miscathus flowers to survive even when being discarded, neglected, or mistreated. This is metaphorical about Taiwanese people's life during Japanese Occupation Era. Retrieved April 30, 2014, from http://blog.ilc.edu.tw/blog/blog/3226/catid=12775.
} 
of miscanthus flowers has implied more than it appears: both Japan and China in this play are regarded as foreign powers and neither of them could represent Taiwan; therefore, Sayonara 1945 strongly suggests the indigenous and native are true Taiwanese, which is the cause of "One Country, Two Worlds" in Taiwan. When Taiwanese people say sayonara to the Japanese reign and the Koumintang Chinese came along, for more than 60 years, many Taiwanese people still feel they do not have a say in their freedom and rights. Recently, with the forceful economic and political threat from China, this play once again reminds Taiwanese people of 1945, which is analogous to the present condition: We already said sayonara to colonization, but we are anxious and uncertain about the future. Will there be another colonization? In between, the Taiwanese could only hang on to what they have and find the way to survive.

\section{An Ambivalent Identity}

Although Sayonara 1945 strongly suggests the indigenous and native are what the Taiwanese would identify with, the form of the play does not respond to the idea; on the contrary, the form is a hybrid product of colonization and cultural exchanges. On the posters and promotion ads, Golden Bough Theatre claims Sayonara 1945 is “Heart Taiwan Magical Musical” (哈台魔幻歌舞劇), a musical form of the Tai style. Actually, this style of the magical musical is a modified and refined form of Opela, a reformed and adapted style of Taiwanese local opera. Of all the traditional arts in Taiwan, Taiwanese opera is considered the only art originated locally and developed on the island. The root of Taiwanese opera is religious, for it is commonly seen during all kinds of rituals or festivals as a public demonstration, which makes it closely related to people's life. Before TV was popular in the 1960s, Taiwanese opera used to be the major form of public entertainment. ${ }^{4}$ One of the reasons for Taiwanese opera to be popular among people is its being accommodating to different political and social realities. The most drastic transformation of Taiwanese opera occurred during the Japanese Occupation Era. At the early stage of the Japanese colonization, the Taiwanese culture and customs were not strictly monitored; on the contrary, the Japanese government tried to understand and preserve all kinds of Taiwanese cultural activities in order to manage this new colony. The political strategy was pacification and assimilation then. However, with the outbreak of the Pacific War (1937-1945), the attitude of the Japanese government changed and it treated Taiwan as a military base for Japan's invasion to South Asia (i.e., the policy of Southern Expansion/南進政策), and issued a series of political and social campaigns to transform Taiwanese people's ways of life. In 1941, the Kominhokokai (the Public Service Association of Imperial Subjects/皇民奉公會) was established to officially "reform” Taiwanese society , and helped all imperial subjects establish extreme patriotic loyalty in their life. This is the Kominka Movement, or Japanization Movement in Taiwan. The Kominka movement actually is a series of political brain-washing campaigns: The colonial government provided economical incentives for people to use the Japanese language and customs, spread the cult of the Japanese Emperor and the Shinto religion, and change Taiwanese people's names and customs. This movement virtually urged the Taiwanese to deny their own culture

\footnotetext{
${ }^{4}$ According to ZENG Yong-yi, CHEN Cong-ming (陳聰明), the director of Taiwanese opera and TV programs, pointed out the golden age of Taiwanese opera should be the 1940s, especially after 1945 when the Japanese colonial government retreated from Taiwan. There were about 300 troupes in Taiwan, and Taiwanese opera was even more popular than movies. This is the time when the art reached maturity. Later in the 1950s, the development of this art reached the summit and there were about 500 troupes, and 30 to 60 persons per troupe. Taiwanese opera was the most popular pubic entertainment at this time (ZENG, 1988, pp. 66-67).
} 
and forced Taiwanese people to identify with Japan solely.

In order to "Japanize" entertainment business in Taiwan, the Kominhokokai issued two principles in “refining” Taiwanese arts: (1) Taiwanese songs and languages were banned from stage, but only Japanese songs and language were officially allowed; (2) All plays should be strictly censored and controlled, including the scripts, contents, and costumes. All performers should wear Kimono and sing Japanese songs (ZENG, 1988, p. 63). Thus, any theatrical production that followed these two principles were regarded as “refined drama” (改良 劇). Under this circumstance, Taiwanese opera was devastated, for the tradition was overthrown and the art was forced to propagandize the Japanization ideal. In order to survive, many opera troupes tried to adapt to this cruel reality and merged Japanese music, performing styles and even imaginary or magical plots, and then a new breed of art, Opela, came into being.

Of all the Taiwanese traditional arts, Opela is the only one that is modified and strongly influenced by the political power. According to SHIH Wan-shun, before the colonial government promoted the Kominka Movement, many Taiwanese opera troupes had already added some pop music or Japanese songs in their performance, and termed their performance as “opera” (Ge-ju/歌劇) instead of using its Taiwanese name, Gezaixi, for the term stands for "western art” and "modernity” (p. 35-36). This is the early form of Opela, which is produced based on the box office consideration and desire for modernity. Shih (2008) thinks at this time Taiwanese people might not have a comprehensive understanding about what opera is, but people were eager to modernize and enrich the traditional arts by merging exotic elements and novel ideas, which makes Taiwanese opera prone to changes and modification (p. 37). Therefore, as the Kominka Movement started to limit that the only aesthetic standard for Taiwanese traditional arts is “de-sinicization” and “Japanization”, Opela survived political persecution and found a way out to preserve Taiwanese culture at the critical moments.

Many critics find it nondescript when it comes to terming Opela, for it presents various music styles and its non-conventional ways of acting which are quite different from orthodox Taiwanese Gezaixi, and some even despise this art for it betrays the tradition and fawns on foreign powers (CHEN, 2005, p. 155). However, being nondescript and subversive to the Taiwanese opera tradition just shapes the uniqueness of Opela. We could find various elements that are popular with the crowds in it, such as flashy light, tacky costume, traditional performing skills, and exotic dance. WANG Rong-yu, director and founder of Golden Bough Theatre, thinks the nature of Opela is collage (YE, 2011, p. 140), a projection of commoners' life and taste. Opela usually features a fusion of traditional and modern theatrical arts, just like a variety show where all kinds of dramatic elements could be accepted and performed onstage.

Therefore, it is significant for Golden Bough Theatre to deal with the conflicting identity issue of the Taiwanese via the form of Opela. The choice itself is ambivalent enough. Though a modified form from Taiwanese opera, Opela is also a reminder of the colonial past, for the background when and where it was nourished. It is a transformation out of the traditional local opera, a hybrid product of various exotic elements. Furthermore, it has been developed based on the ideas of "de-sinicization" and "Japanization". When Golden Bough Theatre claims to choose the local and grassroots path to produce theatrical works, it has-whether consciously or unconsciously - accepted the aesthetic standard established during the colonization era as a part of the Taiwanese culture, and brought it out to the spotlights of National Theatre. This shift of performing locales_from the street demonstration to National Theatre-shows the ambition of Golden Bough Theatre to 
celebrate and centralize Taiwanese local arts and traditions; however, Golden Bough Theatre’s choice of Opela to speak for Taiwanese spirit seems to suggest the ideas of "de-sinicization" and "Japanization" are not the past, but the present condition.

Like miscanthus flowers, Opela is very accommodating and adaptive to various challenges and even threats. Yet, Opela is hardly termed as indigenous, for it has subverted the Chinese cultural heritage and presented distorted Japanese culture. It is sometimes tacky and hilarious, and before Golden Bough Theatre's productions of Opela, it was never a high art. WANG Rong-yu's idea of "One Country; Two Worlds" presented in Sayonara 1945 shows Taiwanese people now are still between political powers. We cannot deny the colonial past and overlook the forceful Chinese power, since Japanese and Chinese cultures are already parts of Taiwanese culture. But the characteristics of "great Taiwanese citizens" are still "under-construction”: No one could give a definite picture, but only an ambivalent image of the Taiwanese.

\section{Conclusion}

According to a poll made by Taiwan Thinkbank in 2013, when asked if Taiwan and China belong to "One China”, or they are two different countries, $79.9 \%$ of Taiwanese people replied they think Taiwan and China are two different countries. In terms of self-identification, $78 \%$ of people see themselves as Taiwanese, $7.8 \%$ think they are Chinese, while $10.8 \%$ view themselves as both. ${ }^{5}$ The statistics show the majority of Taiwanese people's self-identification does not correspond to "One China Policy" that has long been recognized officially and internationally. There seems to be a gap between what Taiwanese people think they are and what the government or other countries think the Taiwanese are. Sayonara 1945 allegorizes the present conflicting self-identification of Taiwanese people with a fictional scenario when Taiwanese people actually have to choose their national identity. The play raises the question who Taiwanese are instead of giving a definitive answer, which reflects the truth of Taiwanese conflicting self-image. Now facing China who sticks on "One China Policy” and its strong economic and political power, at the same time the anxiety and fear of being "colonized" are evoked in many Taiwanese people’s mind. It seems 1945 does not go away from people’s memories; it lingers and still haunts Taiwan.

\section{References}

CHEN, H. L. (2005). The combination of the outdoor Taiwanese opera and popular culture-In the light of the development of O-pei-la-hi. Arts Journal, 10, 151-165.

CHEN, W. H. (2010). 曲韻悠揚: 台灣傳統戲曲歌仔戲 (Melodious tunes: Traditional Taiwanese opera). Taipei: LiWen Publishers.

HO, W. C. (2007). Music and cultural politics in Taiwan. International Journal of Cultural Studies, 10(4), 463-483.

HSIEH, H. M. (2007). From "Refined Gezaixi” to "Opela”: Discourses of Gezaixi under the changing Taiwanese national identity. Journal of Chinese Ritual, Theatre and Folklore, 155(3), 79-110.

LEE, S. Y. (2011). Introduction to Traditional Theatrical Arts in Taiwan. Taichung: China Medical University.

SHIH, W. S. (2008). Glimmers from a dark age: Taiwanese Theatre under the Kominka Movement (1936.9 1940.11). Journal of Chinese Ritual, Theatre and Folklore, 159(3), 7-81.

SILVIO, T. J. (2009). The nostalgic community and the reintegrated individual: The "New Opeila” performances of the Golden Bough Theatre and the Formosa Zephyr Opera Troupe. Journal of Theatre Studies, 4, 45-74.

5 See “Taiwanese attitudes toward cross-strait relations: Findings from the polls". Retrieved April 30, 2014, from http://www.taiwanthinktank.org/page/chinese_attachment_1/2704/Taiwanese_Attitudes_Towards_Cross_strait_relations.pdf. 
Taiwan Thinkbank. (2013). Taiwanese attitudes toward cross-strait relations: Findings from the polls. Retrieved from http://www.taiwanthinktank.org/page/chinese_attachment_1/2704/Taiwanese_Attitudes_Towards_Cross_strait_relations.pdf XIAN, Y. Y. (2005). Call Me Tai Ke ! = Call Me TK! Taipei: Net and Books.

YE, Z. H. (2011). 難忘的心愛的人：金枝演社的胡僘仔美學 (My unforgettable lover: The Opela aesthetic of Golden Bough Theatre). New Taipei City: Fa Yan Quan (發言權).

ZENG, Y. Y. (1988). 台灣歌仔戲的發展與變遷 (The development and changes of Taiwanese opera). Taipei: Linking Publishing. 